\title{
INFLUENCE OF HIGHER ORDER NEED STRENGTH AND JOB CHARACTERISTICS ON JOB PERFORMANCE
}

\author{
C.J.H. BLIGNAUT ${ }^{1}$
}

AFRICAN EXPLOSIVES AND CHEMICAL INDUSTRIES. SASOLBURG

and

I. VAN W. RAUBENHEIMER ${ }^{2}$

DEPARTMENT OF INDUSTRIAL PSYCHOLOGY UNIVERSITY OF SOUTH AFRICA

\section{OPSOMMING}

\begin{abstract}
Kontemporêre motiveringsteorieë in die Bedryfsielkunde word geklassifiseer in twee groepe naamlik (1) dié wat berus op die basiese aanname dat alle werknemers hoëvlak behoeftes het en die bevrediging daarvan sal nastreef solank die inhoud van die werk dit moontlik maak en (2) dié wat op die aanname berus dat sielkundig gunstige werksinhoud waarskynlik hoëvlak behoeftebevrediging tot gevolg sal hê, afhangende van hoe die individu die werksituasie waarneem. 126 Werknemers in 'n Suid-Afrikaanse chemiese nywerheid is by 'n eksperiment betrek waarin bogenoemde basiese aannames teenoor mekaar gestel is. Data ten opsigte van die sielkundige waarde van werksinhoud, hoëvlak behoeftebevrediging en werksprestasie dien as inset tot 'n $2 \times 2$ faktoriale ontwerp. Resultate dui daarop dat hö̈-orde behoeftebevrediging geen beduidende bron van variasie verteenwoordig nie maar die sielkundige waarde van werksinhoud wel $(p<, 01)$ - 'n bevinding wat die kategorie (1) teorieë sterk steun. Geen interaksie-effek kon geïsoleer word nie.
\end{abstract}

Following the classic Hawthorne studies of the late '20's and early '30's (Roethlisberger and Dickson, 1939) which generally made researchers and managers aware of the influence of "human" variables on job performance, scores of studies have been conducted over the years to investigate the specific implications and consequences of the Hawthorne results to the world of work.

In this process not only job performance, but a number of other variables such as job satisfaction, absenteeism, group cohesiveness, financial incentives, turnover, etc., have been studied, with the implicit (if not explicit) assumption that the latter would generally be related

\footnotetext{
${ }^{1}$ Presently at the Human Resources Laboratory of the Chamber of Mines, Johannesburg.

${ }^{2}$ Presently at the University of Stellenbosch.
} 
to job performance. The "robustness" of this assumption has been challenged in various studies (e.g. Brayfield and Crockett, 1955 and Vroom, 1964) but no satisfactory general theory of job performance has yet been advanced.

A number of theoretical positions, however, are being entertained that relate the complexities of human motivation to job performance (Campbell, et.al., 1970, 341-84).

Considering some of the presently more influential of these theories in industrial psychology one could distinguish between (1) those based on the underlying assumption that all individuals possess higher level needs, are capable of satisfying and will indeed satisfy such needs provided the job situation incorporates the conditions or characteristics that make satisfaction possible and (2) those theories that suggest that an individual may or may not be motivated by certain job characteristics depending on whether he in fact has specific (higher level?) needs to be fulfilled and whether he views the job situation as conducive to need satisfaction.

The difference Campbell, .et. al. (1970) observe between content theories and process theories, roughly relates respectively to category 1 and category 2 in the present discussion.

The distinction to be highlighted between category 1 and category 2 theories, however, is that in the former the individual is regarded as possessing certain needs and as having little control over the fact that he will be motivated if subjected to the "right" job conditions, while in the latter there is a definite probability related to being motivated, depending on the individual's specific needs and his perception and evaluation of a specific situation.

Maslow's (1943) theory of human motivation, McGregor's (1960) theory X and theory Y, Herzberg, Mausner and Snyderman's (1959) two-factor theory and Argyris' (1965) concept of personality development, all belong to category 1 in the sense that the individual is seen as having innate potentional for self-development and growth and whenever job characteristics, or the psychological value of the job content, are favourable, it will indeed occur.

The different concepts put forward under these theories such as self-actualization (Maslow); personality development (Argyris) integration of needs (McGregor) and psychological growth (Herzberg, et.al.) seem to reflect different facades of the same structure.

Although Argyris tends to relate personality development to organisational structuring and its consequences and McGregor seems to associate his notion of the integration of individual and organisational needs with the process of management, one could argue that these approaches to higher order need satisfaction are not entirely different to that of Herzberg who 
claims that the job itself is the most important stimulis for intrinsic motivation and development.

Vroom's (1964) theory of motivation, as well as more recent models of expectancy theory and equity theory, to which much attention is being given lately (Campbell, et.al., 1970, Hackman and Lawler, 1971; Henneman and Schwab, 1972; Dachler and Mobbey, 1973; Jorgenson, Dunnette and Pritchard, 1973 to name a few) differ from the aforementioned theories with respect to the role ascribed to the individual in a motivating situation and could therefore be thought of as belonging to category 2. According to these theories the individual has some "control" over the motivating situation to the extent that the situation may or may not be viewed by him as stimulating and potentially satisfying to his needs. Thus, being exposed to jobs with a favourable psychological content does not necessarily lead to motivated behaviour. Under category 1 theories such an outcome is implied or at least expected.

Reasoning contrary to category 1 theories one could argue that if individuals differ with respect to a desire for, say, higher order need satisfaction, job characteristics instrumental to higher order need satisfaction, would enhance motivation and hence job performance only of those individuals with a relatively strong desire for higher order need satisfaction. Thus, the desire for higher order need satisfaction could be expected to affect the influence job characteristics have on job performance.

If such an effect could be demonstrated, it could further be argued that the motivating power of job characteristics (as implied by category 1 theories) are in fact subject to the degree to which higher order needs do exist within individuals.

It should be mentioned at this stage that Hackman and Lawler (1971) attempted to demonstrate an overall moderating effect of strength of higher order need satisfaction on the relationship between job characteristics and dependent variables such as motivation, performance, satisfaction, involvement and absenteeism.

Looking specifically, however, at the data they present (Op.cit., Table 10, p.279) to demonstrate the moderating effect on the relationship between the six job characteristics and three job performance measures used in their study, it will be evident that their conclusion in this regard should be treated cautiously. Not only was the average need strength of the high and low performance groups not much different (6,78 vs. 5,09 with a maximum need strength score of 7) but the differences in correlation between the high and low groups were negligible 
while only one of the six correlation coefficients intended to demonstrate the moderating effect was significant. The relationship between higher order need satisfaction and job performance, thus, remains to be somewhat evasive.

To investigate the notion that the impact of job characteristics (which are defined in this study as the psychological value of job content), conducive to job performance are subject to variations in individual needs (i.e. needs for higher order need satisfaction), the following research strategy could be adopted:

In order to "relate" higher order need satisfaction to the psychological value of job content both should be defined in terms of the same dimensions.

Furthermore, Ss should be divided into two groups - group $\mathrm{N}_{\mathrm{h}}$ with a stronger desire to satisfy higher order needs than group $\mathrm{N}_{1}$. Similarly, the jobs on which Ss performed should be divided into two groups according to their psychological value or potential for satisfying higher order needs - group $\mathrm{J}_{\mathrm{h}}$ with greater opportunity to satisfy higher order needs than group $\mathrm{J}_{1}$.

If there were no significant difference in job performance of Ss in the strong $\left(\mathrm{N}_{\mathrm{h}}\right)$ and weak $\left(\mathrm{N}_{1}\right)$ higher order need satisfaction groups, working on jobs with high psychological content value $\left(\mathrm{J}_{\mathrm{h}}\right)$, it could be reasoned that higher order need satisfaction does not moderate the relationship between job performance and job characteristics and vice versa.

On the other hand, if $\mathrm{Ss}$ in either group $\mathrm{N}_{\mathrm{h}}$ or $\mathrm{N}_{1}$ do perform differently on jobs with high $\left(\mathrm{J}_{\mathrm{h}}\right)$ and with low $\left(\mathrm{J}_{1}\right)$ psychological content values, the potency of category 1 theories, which postulate that all individuals are prone to and will show self-development if job characteristics are favorable, would probably be demonstrated.

The strategy outlined above would then result in the following combinations: 
(i) Combination 1 with $\mathrm{Ss}$ in group $\mathrm{N}_{\mathrm{h}}$ performing on jobs in group $\mathrm{J}_{\mathrm{h}}$.

(ii) Combination 2 with $\mathrm{Ss}$ in group $\mathrm{N}_{1}$ performing on jobs in group $\mathrm{J}_{1}$.

(iii)Combination 3 with $\mathrm{Ss}$ in group $\mathrm{N}_{h}$ performing on jobs in group $\mathrm{J}_{1}$.

(iv) Combination 4 with $S$ s in group $N_{1}$ performing on jobs in group $J_{h}$.

Figure 1 provides an illustration of the research strategy.

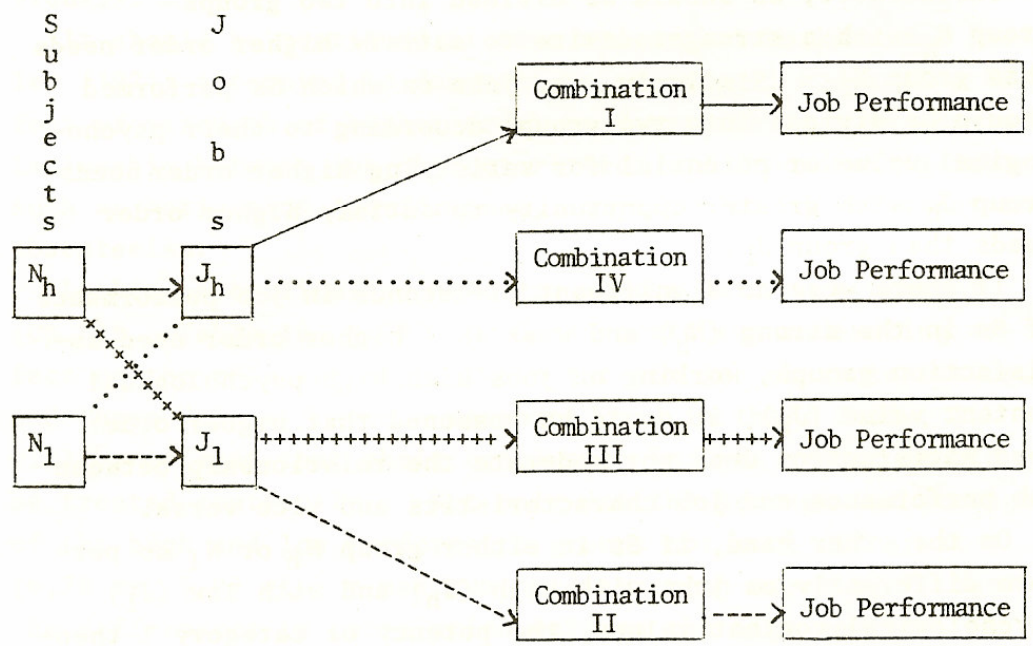

Figure 1. Diagrammatical presentation of research strategy.

The aforementioned research strategy in effect represents a $2 \times 2$ factorial experiment (two levels of job content vs. two levels of higher order need satisfaction) which calls for an analysis of variance to determine whether any main and interaction effects are present.

Once any of these effects are demonstrated to be significant, post hoc comparisons between the means of the different group combinations would be in order.

\section{METHOD}

In order to perform the said analyses, it was necessary to obtain measurements on (a) higher order need strength (b) the psychological value of job contents and (c) job performance.

Data were obtained from 126 chemical process operators on 36 jobs in a large chemical industry. Participation in the research was voluntary, the general purpose of the research was explained and assurance had been given that the results of the study would be used for research purposes only. 
The dimensions used to evaluate the existence and strength of higher order needs were also used to describe the psychological value of the jobs involved in this study and are listed in Table $1^{*}$.

TABLE 1

Dimensions and Rating Scales for Determining Higher Order Need Strength and the Psychological Value of Job Contents

\begin{tabular}{|c|c|}
\hline Dimension & Rating \\
\hline $\begin{array}{l}\text { 1. Responsibility } \\
\text { "(a) Participation in and/or opportunity for } \\
\text { independent action and thought } \\
\text { (b) Control and verification of work } \\
\text { 2. Performance } \\
\text { (a) Opportunity to perform whole jobs } \\
\text { (b) Visiblity and extent of transformation } \\
\text { 3. Acknowledgement } \\
\text { (a) Acknowledgement through job itself } \\
\text { (b) Acknowledgement by others } \\
\text { 4. Growth and learning } \\
\text { (a) Application (utility of skills and abilities) } \\
\text { (b) Development of additional skills and abili- }\end{array}$ & $\begin{array}{lllllll}1 & 2 & 3 & 4 & 5 & 6 & 7 \\
1 & 2 & 3 & 4 & 5 & 6 & 7\end{array}$ \\
\hline
\end{tabular}

*Each subdimension was actually circumscribed in an additional paragraph to convey its meaning as clearly as possible.

\section{Measurement of higher order need strength}

Only a few studies relating to higher order need strength could be found in the literature. This is probably due to the "discouraging" reality that the complexity of human needs increases as one moves up the need hierarchy due to the abstract nature and diversity of higher order needs (Vlok, 1967).

On the basis of Alderfer's (1967) finding, that there is little choice between interviews and questionnaires particularly when it comes to measuring the intensity of need satisfaction and desire, it was decided to use the interview for measuring strength of high order needs.

\footnotetext{
* The attempts of Alderfer (1959), Porter (1961), Herzberg, et. al., (1959) and Hackman and Lawler (1971) provided useful guidelines in identifying and defining suitable dimensions. 
In addition to using the definitions provided in Table 1 as guidelines in the interview, the strategies of Herzberg et. al. (1959) and Porter (1961) were adopted and slightly modified in an attempt to obtain reliable data. Each Ss, at the beginning of the interview, was asked by one of the researchers to describe a job or task, not necessarily in his present employment, at which he felt the happiest and gave his best performance. Using the Porter type of scale Ss were next asked with regard to each dimension in Table 1: (i) Tell me more about how your job was (for instance) planned? (ii) How did you feel about it and (iii) How would you have preferred your job to be planned? By basing his judgement on responses to these questions the interviewer judged the strength of each need dimension on a seven point scale. A total need strength score was obtained for each Ss by summing the scale values across the eight subdimensions in Table 1.

\section{Measurement of the psychological value of job content}

As the study of Hackman and Lawler (1971) indicated that fairly strong agreement exists between the objective evaluation of job content by supervisors and investigators and the subjective evaluation by incumbents, it was decided to base the measurement of the psychological value of job content on a variation of the objective direct point method of job evaluation as it is used in wage and salary administration.

As a first step in developing the instrument, each of the eight sub dimensions in Table 1 was divided into five grades by means of appropriate interval definitions. Although it was attempted to establish grades into equal, continuous and mutually exclusive units, variations in grade values were provided for by the allocation of numerical values. This would also facilitate finer assessments. The next step involved the compilation of an evaluation guide which included the evaluation procedure and the definitions of dimensions and grades. The last step demanded that a team of judges be trained. The judges of each job included one investigator, a training officer and a supervisor. In each case the panel had to be in agreement on the numerical value (ranging from 1 to 10) allocated to each sub dimension.

A total job content score was obtained for each of the 36 jobs by summing the scale values across the eight sub dimensions. The following is an example of the sub dimension "Development of additional skills and abilities" as it appeared in the manual. 
This sub dimension refers to the extent to which the job provides opportunities to develop (new) skills and abilities. Some aspects to consider are:

- Challenge and variety in the job

- Changes in job content

- Performance on "lesser" jobs

\section{DESCRIPTION}

Once trained on the job, the job becomes

A matter of simple routine which adds

Nothing to acquire skills and abilities

Once trained on the job, the job becomes

Routine and hardly adds to skills and

Abilities

The job provides for moderate additions

To skills and abilities

The job provides significant additions to

Skills and abilities

The job demands continuous development

Of skills and abilities

\section{DEGREE VALUES}

Possible Allocations

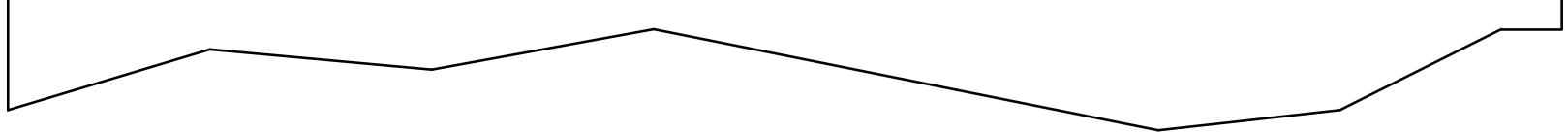

\section{Measurement of job performance}

Due to the nature of, the job performed by Ss, supervisory ratings had to be used as indices of job performance. Existing performance assessment records were obtained from the personnel department of the organisation at which the study was conducted. In establishing these records, supervisors are required to rate the performance of employees along the fol- 
lowing eight dimensions using seven grade categories: Industriousness, quality of work, ability to work without supervision, initiative, co-operation with others, estimation of maintenance needs, efforts toward orderliness and accident prevention and leadership. One such dimension is shown below:

\begin{tabular}{|l|l|l|l|l|l|l|}
\hline \multicolumn{1}{|c|}{2} & \multicolumn{1}{|c|}{3} & \multicolumn{1}{c|}{4} & \multicolumn{1}{c|}{5} & \multicolumn{1}{c|}{6} & \multicolumn{1}{c|}{ Quality of Work } \\
\hline $\begin{array}{l}\text { Work } \\
\text { is never } \\
\text { good } \\
\text { enough }\end{array}$ & $\begin{array}{l}\text { Work is } \\
\text { often } \\
\text { not } \\
\text { good } \\
\text { enough }\end{array}$ & $\begin{array}{l}\text { Work } \\
\text { is } \\
\text { some- } \\
\text { times } \\
\text { not } \\
\text { good } \\
\text { enough }\end{array}$ & $\begin{array}{l}\text { Work is } \\
\text { usually } \\
\text { just } \\
\text { good } \\
\text { enough }\end{array}$ & $\begin{array}{l}\text { Work is } \\
\text { always } \\
\text { good } \\
\text { enough } \\
\text { and } \\
\text { some- } \\
\text { times } \\
\text { really } \\
\text { well } \\
\text { done }\end{array}$ & $\begin{array}{l}\text { Work } \\
\text { is } \\
\text { always } \\
\text { good } \\
\text { enough } \\
\text { and } \\
\text { often } \\
\text { really } \\
\text { well } \\
\text { done }\end{array}$ & $\begin{array}{l}\text { Work } \\
\text { is } \\
\text { always } \\
\text { really } \\
\text { well } \\
\text { done }\end{array}$ \\
\end{tabular}

A job performance score was obtained for each Ss by summing the numerical value of each relevant grade category across the eight dimensions.

After the measures on higher order need strength, psychological value of job content and job performance, were obtained, the Ss and the jobs were grouped according to the research design into high and low data groups as in Table 2.

Furthermore, Ss in the high and low need strength groups were assigned to the high and low job groups in order to establish the four group combinations with a view to performing the analysis of variance (F-test with unequal cell frequencies - Winer, 1962, 241-243) as spelled out by the research paradigm. 
TABLE 2

Higher Order Need Strength Score and Psychological Job Value Scores for 126 Ss in High and Low Data Groups

\begin{tabular}{|c|c|c|c|c|}
\hline \multirow{4}{*}{$\begin{array}{l}\text { Higher order need } \\
\text { Strength scores }\end{array}$} & \multirow{4}{*}{$\begin{array}{l}\text { High } \\
\text { Low }\end{array}$} & \multicolumn{2}{|c|}{ Scores } & \multirow[b]{2}{*}{$\mathrm{n}$} \\
\hline & & Range & Average & \\
\hline & & $32-49$ & 38.0 & 62 \\
\hline & & $15-31$ & 24.7 & 64 \\
\hline \multirow[t]{2}{*}{ Job value scores } & High & $44-61$ & 52.2 & 54 \\
\hline & Low & $22-43$ & 31.2 & 72 \\
\hline
\end{tabular}

\section{RESULTS AND DISCUSSION}

\section{The effect of higher order need strength}

The results summarised in Table 3 pertain to the effect of higher order need strength on job performance under job conditions of high and low psychological value.

TABLE 3

Analysis of Variance of Job Performance Scores

\begin{tabular}{|l|r|r|c|}
\hline \multicolumn{1}{|c|}{ Sources of Variation } & df & MS & F \\
\hline Higher order need strength $(\mathrm{N})$ & 1 & 16,05 & 0,93 \\
Job content (J) & 1 & 595,25 & $34,32 \%$ \\
$\mathrm{~N}$ X J & 1 & 0,06 & 0,00 \\
Within cell (error) & 122 & 17,17 & \\
\hline
\end{tabular}

$" \mathrm{p}<, 01$

As can be seen from Table 3, higher order need strength does not represent a significant source of variation. Also no significant interaction effect between higher order need strength and the psychological value of job content could be found; indicating that individual differences in higher order need strength do not influence the reaction of employees to the psychological value of their job contents i.e. members in groups $\mathrm{N}_{h}$ and $\mathrm{N}_{1}$ working under the same favorable (job group $\mathrm{J}_{\mathrm{h}}$ ) or unfavorable (job group $\mathrm{J}_{1}$ ) motivating conditions would not, on the average, perform significantly different. 
According to our expectation this should not have occurred since individuals with a relatively strong desire for higher order need satisfaction being exposed to job conditions that would foster such need satisfaction should be more motivated and thus perform better than those with a relatively weak desire exposed to the same job conditions.

\section{Effect of the psychological value of job content}

Reference to Table 3 and particularly with regard to job content as a source of variation suggests that, regardless of individual differences in higher order need strength job content has potential of influencing job performance. In fact, the correlation between these two variables turned out to be, $6(\mathrm{p}<, 01)$. Referring to the mean performance scores (Table 4$)$ it will be noticed that the job performance of Ss in combination groups I and IV i.e. with greater job opportunities to satisfy higher order needs, was better than the job performance of Ss in combination groups II and III with lesser opportunity to satisfy higher order needs. These data make out a rather strong case for category 1 theories which heavily emphasise the meaning of the psychological value of job content in employee motivation.

TABLE 4

Number of Ss and Average Performance Scores

for Each Group Combination

\begin{tabular}{|c|c|c|}
\hline Combination & $\mathrm{n}$ & $\begin{array}{c}\text { Average Job } \\
\text { Performance } \\
\text { Scores }\end{array}$ \\
\hline I & 35 & 37,5 \\
II & 45 & 33,7 \\
III & 27 & 33,0 \\
IV & 19 & 38,3 \\
\hline
\end{tabular}

Some of the data collected to describe the sample of subjects (i.e. age, years at school, average income and length of service), it was thought, could probably explain the difference in performance between combination groups I, IV and II, III. Analysis of the data indicated, however, that no significant differences existed between the two groups on these variables except for average income.

Before taking these findings too seriously, it seemed appropriate to further investigate income as the only variable on which the combination groups (i.e. I, IV vs. II, III) did differ. Following from the above information, it was argued that income should correlate with job performance to a significant degree. Analysis of the data did in fact indicate this. It was 
found that the correlation between monthly income and job performance $(r=, 47)$ was significant $(\mathrm{p}<, 01)$.

It should be noted that the company at which the study was conducted, determines wage rates by means of a formal job evaluation programme. This implies that the monetary value of jobs is based on the objective value of jobs. Although one could not conclude from this that there necessarily exists a relationship between the objective (financial) and psychological value of jobs. it should, however, be pointed out that these two values need not be independent.

Considering all the facts and arguments offered, it seems in order to conclude that the better job performance of combination groups I and IV is probably due to the greater psychological value of job content these Ss enjoyed over those in combination groups II and III.

One would hesitate, however, to suggest that, on the basis of this study, the basic premise of category 2 theories (as defined in this study) can be expected to be "inferior" to that of category 1 theories. Category 2 theories rely heavily on the decision and judgemental properties of the individual. It also implies that the individual has a free choice in selecting behaviours instrumental to obtaining a desired outcome. In practice such privileges usually belong to higher level jobs. The kind of jobs studied in this research (process operators setting up production processes according to fixed methods and stipulations and controlling these processes by way of scanning control panels and making necessary adjustments) cannot be considered as involving a great deal of free choice in the kinds of activities employees engage in. In fact, the data (Table 2) support this notion to some extent since the highest job content value score obtained was 61 out of a maximum of 80 . Any improvement on the psychological value of job content imposed on a job would probably enhance job performance on jobs that do not allow for much individual variety in need satisfaction. Category 2 theories on the other hand would most probably be more powerful in explaining human motivation at high level managerial jobs.

This, on the other hand, should not be viewed as degrading the value of category 1 theories in explaining employee motivation. Too many jobs in our society are geared (perhaps unintentionally) toward satisfying lower level needs while many low level jobs can be made psychologically meaningful. 


\section{SUMMARY}

Contemporary theories of work motivation are classified according to (1) those based on the underlying assumption that all individuals posses higher level need, are capable of satisfying and will indeed satisfy such needs provided the job situation incorporates the conditions or characteristics that make satisfaction possible and (2) those theories suggesting that an individual may or may not be motivated by certain job characteristics depending on whether he in fact has specific (higher level) needs to be fulfilled and whether he views the job situation as conductive to need satisfaction. 126 Subjects employed by a chemical industry took part in an experiment designed to test the basic assumptions underlying the aforementioned theories. Data relating to higher order need satisfaction, the psychological value of job content and job performance served as input to a $2 X 2$ factorial analysis. Results indicate that only the psychological value of job content represented a significant source of variation $(p<, 01)-a$ finding which favours category (1) theories to a large extent. No significant interaction between the latter source of variation and higher order need satisfaction could be found.

\section{REFERENCES}

Alderfer, C.P. Convergent and discriminant validation of satisfaction and desire measures by interviews and questionnaires. Journal of Applied Psychology, 1967, 51, 509-520.

Argyris, C. Personality and Organization. New York: Harper and Row, 1965.

Brayfield, A.H. and Crockett, W.H. Employee attitudes and employee performance. Psychological Bulletin, 1955, 52, 396-424.

Campbell, J.P., Dunnette, M.D., Lawler, E.E. III and Weick, K.E. Managerial Behavior, Performance and Effectiveness. New York: McGraw-Hill, 1970.

Dachler, H.P. and Mobley, W.A. Construct validation of an instrumentability-expectancy task-goal model of work motivation. Journal of Applied Psychology, 1973, 58(3), 397418.

Hackman, J.R. and Lawler, E.E. III. Employee reactions to job characteristics. Journal of Applied Psychology, 1971, 55(3), 259-286.

Henneman, H.G. and Schwab, D.P. Evaluation of research on expectancy theory predictions of employee performance. Psychological Bulletin, 1972, 78, 1-9.

Herzberg, F., Mausner, B. and Snyderman, B.B. The Motivation to Work.

New York: Wiley, 1959.

Jorgenson, D.O., Dunnette, M.D. and Pritchard, R.D. Effects of the manipulation of a performance-reward contingency on behavior in a simulated work setting. Journal of Applied Psychology, 1973, 57(3), 271-280.

Maslow, A. A theory of human motivation. Psychological Review, 1943, 50, 370-396.

McGregor, D. The Human Side of Enterprise. New York: McGraw-Hill, 1960.

Porter, L.W. A study of perceived need satisfactions in bottom and middle management jobs. Journal of Applied Psychology, 1961, 45, 1-11. 
Pritchard, R. D. and Sanders, M. S. The influence of valence, instrumentability and expectancy on effort and performance. Journal of Applied Psychology, 1973, 57(1), 5560.

Roethlisberger, F.J. and Dickson, W.J. Management and the Worker. Cambridge, Mass: Harvard University Press, 1939.

Vlok, A. Agtergrond vir Personeelsielkunde. Pretoria: Van Schaik, 1967.

Vroom, V.H. Work and Motivation. New York: Wiley, 1964.

Winer, B.J. Statistical Principles in Experimental Design. New York: McGraw-Hill, 1962. 